UDK 781:130.2:165.75

\title{
Christopher Norris
}

Univerza Cardiff, Anglija

Cardiff University, UK

\section{In Defence of 'Structural Hearing': Some Problems With the New Musicology}

\author{
V zagovor 'strukturnega poslušanja': \\ nekatere težave Nove muzikologije
}

Ključne besede: estetika, dekonstrukcija, de Man, formalizem, ideologija, Kerman, teorija glasbe, Shenker, 'strukturno poslušanje'

\section{POVZETEK}

Prispevek obravnava vrsto vsebin s področja novejših usmeritev teorije glasbe. K njim sodi nasprotovanje 'analizi' ali 'strukturnemu poslušanju' kot (domneven) prispevek Nove muzikologije $\mathrm{v}$ diskurz mainstream muzikologije, katere namen naj bi bil nenehno obnavljanje kanona priznanih 'mojstrovin' in vrsta elitističnih vrednostnih sodb, ki so običajno naslovljene na taka dela. $\mathrm{K}$ temu sodi ideja - izpeljana po Paulu de Manu in predstavnikih literarne dekonstrukcije -, da bi mogli imeti pojmi, kot so 'organska forma', strukturna enovitost, tematska povezanost, celovit tonalitetni ali harmonski razvoj itn. in so razumljeni kot rezultat določene 'estetske ideologije' za sumljive, celo usodne posledice, če bi jih uporabili na širšem polju kulturne politike. Menim, da je to zgrešena ali vsaj zelo tendencionzna miselnost, ki sama nedopustno transponira pojme iz enega (literarnoteoretskega) področja, kjer tovrstni argumenti imajo določeno moč, na drugo (glasbenoteoretsko)
Keywords: aesthetics, deconstruction, de Man, formalism, ideology, Kerman, music theory, Schenker, 'structural listening'

\section{ABSTRACT}

This essay raises a number of issues with regard to recent developments in music theory. Among them is the turn against 'analysis' or 'structural listening' on account of their (supposed) investment in a discourse of mainstream musicology whose aim is to perpetuate the canon of acknowledged 'great works' and the kinds of elitist value-judgement that are conventionally applied to such works. Along with this goes the idea - derived from Paul de Man and exponents of literary deconstruction - that notions such as those of 'organic form', structural unity, thematic integration, long-range tonal or harmonic development, etc., are products of a certain 'aesthetic ideology' with dubious, even sinister, implications when transposed to the wider realm of cultural politics. I maintain that this is a false, or at any rate a highly tendentious line of thought which itself involves the illicit transposition from one domain (that of literary criticism) where such arguments have a certain force to another (that of music 
področje, kjer preprosto ne vzdržijo kritike drugače kot $\mathrm{z}$ močno in nezadovoljivo raztegljivostjo po načelu analogije. Takó je zoperstavljanje naivnemu organicističnemu branju poetične metafore pri de Manu, ki domneva neposredno kontinuiteto (celo identičnost) med umom in naravo, subjektom in objektom, ali jezikom in pojavno intuicijo, pri prenosu na področje naše čutne glasbene izkušnje, ki je tudi konceptualno podprta, izrazito neustrezno.

Nakazana vprašanja skušam podajati skozi branje različnih teoretikov z obeh strani debate, vključno z Adornom, čigar poudarjanje kreposti 'strukturnega poslušanja' kot sredstva upora proti rutinskim, v navado otrdelim ali ideološko pogojenim načinom odzivanja ponuja morda najbolj mogočen ugovor novejšim nasprotovanju analizi $v$ vseh njenih oblikah. Nadalje tudi dodajam, da so bile te oblike analize veliko bolj raznolike - in pogosto manj predane organicistični veri - kot jih skušajo predstaviti njihovi obrekovalci, ki nagibajo k enačenju 'analize' z analitično metodo Heinricha Schenkerja in njenim v temelju konservativnim, dogmatskim in ideološko obremenjenim pristopom. V podporo svojemu protiargumentu se sklicujem na različne smernice kognitivne znanosti in psihologije percepcije skupaj $z$ nedavno debato med filozofoma Petrom Kivyjem in Jerroldom Levinsonom, ki zadeva močno kontroverzno tezo slednjega, namreč da je razumevanje glasbe zamejeno na časovno zelo kratke odlomke (spominskega in anticipatoričnega) dojemanja. Izvajanje sklenem $\mathrm{z}$ mislijo, da je mogoče naše presojanje glasbe krepko poglobiti in obogatiti z različnimi vrstami trajnostnega ali dolgosežnega strukturnega dojemanja glasbenega toka, kot ga skuša razkriti analiza, in da je katera koli teorija, ki to izključuje - ali znižuje na golo 'estetsko ideologijo' -, ipso facto na napačni poti. theory) where they simply don't apply unless by a great and implausible stretch of analogy. Thus de Man's case against naïvely organicist readings of poetic metaphor which assume a direct continuity (even identity) between mind and nature, subject and object, or language and phenomenal intuition must appear distinctly off-the-point when applied to our sensuous but also conceptually-informed experience of music.

My essay pursues these questions via a reading of various theorists on both sides of the debate, including Adorno, whose emphasis on the virtues of 'structural listening' as a means of resistance to routine, habitual, or ideologically conditioned modes of response offers perhaps the most powerful rejoinder to this current revolt against analysis in all its forms. I go on to remark that those forms have been far more diverse - and often less committed to a hard-line organicist creed - than their detractors like to make out, tending as they do to equate 'analysis' with Heinrich Schenker's deeply conservative, dogmatic, and ideologically-loaded approach. In support of my counter-argument I draw on various developments in cognitive science and the psychology of perception, along with a recent debate between the philosophers Peter Kivy and Jerrold Levinson concerning the latter's highly controversial claim that musical understanding is limited to very short stretches of temporal (retentive and anticipatory) grasp. I conclude that our appreciation of music can be greatly deepened and enriched by the kinds of sustained or long-range structural comprehension that analysis seeks to provide, and that any theory which rules this out or puts it down to mere 'aesthetic ideology' - is ipso facto on the wrong track. 


\section{1}

It is a long time - getting on for a century - since literary critics first became involved in earnest (often heated) debate about the relative merits of 'appreciative' and 'analytic' criticism. In fact one can date the most significant outbreak to the period just following the 1930 publication of William Empson's Seven Types of Ambiguity, a text that is nowadays perhaps more talked about than actually read but which remains (in my judgement) altogether unsurpassed for sheer brilliance, acuity, analytic insight, and - be it said - occasional flights of soaring freeassociative fancy (Empson 1930). No work since then has come anywhere close to Seven Types for the extent of its influence (especially on the US New Criticism) and the way that it opened up new possibilities of detailed textual exegesis combined with the strongly speculative bent of a first-rate analytical intelligence. Indeed it is fair to say that this transformative impact was as much upon the poems or passages that Empson singled out for scrutiny as upon those receptive - and to that extent 'appreciative' - readers for whom poetry would never be quite the same again. Nevertheless the book attracted, and continues to attract, a good deal of hostile commentary from two main quarters. On the one hand are scholar-critics, like Rosamond Tuve, who have attacked Empson for his flagrant 'misreadings', most often brought about they claim - through his blithely anachronistic approach or cavalier disregard for the standards of interpretative truth imposed by a due respect for the constraints of philological research, authorial intent, and period-based generic convention. (See for instance Tuve 1952.) On the other - more relevant in the present context - is the charge brought against him by those who maintain that our experience of poetry is first and foremost a matter of 'appreciation', that is to say, an intuitive mode of response that cannot - or should not - be subject to any such pleasure-destroying excesses of analytic rigour.

This objection was voiced by John Sparrow in an article, published in the journal Oxford Outlook, to which Empson replied with a vigorous defence of his own, typically 'Cambridge' outlook of sturdy scientific rationalism versus Sparrow's typically 'Oxford' offence at the idea of having his fine-tuned aesthetic responses so rudely laid open to inspection (Empson 1987: 193-202; also Sparrow 1930: 598ə607). In other words, there was no real danger that (in Empson's phrase) by 'pruning down too far toward the emotional roots' the critic might thereby destroy the delicate flower. Any good poem, i.e., one that merited such close analytical attention would surely stand to gain through this process of helping the reader to appreciate at a more conscious or reflective level what had hitherto been largely a matter of inchoate, illdefined emotive response. And again, if the poem - or the reader's enjoyment - was spoiled by the analyst's approach then most likely that enjoyment was misplaced, whether because the poem didn't deserve it or because the reader was responding in some wrong or inappropriate (e.g., emotionally self-indulgent) way. Thus, for Empson, the chief virtue of analytic criticism was in drawing conscious attention to a range of otherwise unnoticed (or subliminal) nuances and depths of meaning, and thereby offering the reader a firmer, more confident basis for arriving at judgements of value. At the same time it could happily avoid the kind of vague, unsupported, or downright dogmatic evaluative talk that all too often resulted when critics like Sparrow fell back on the appeal to unaided intuition as the sole arbiter of aesthetic or literary worth. That is to say, any judgement could be taken as implicit in the fact that the poem or passage concerned had not only been singled out for close attention but shown itself responsive to an analytic treatment whose success - in so far as it achieved its aims - was sufficient guarantee of such worth. At this stage opponents are likely to object that the whole process has become purely circular, since 'good' poetry is now defined as just the sort that lends itself best to the analyst's foregone methods and predilections, while these are in turn borne out by 
(what else?) their working so well with the poetry in question. To which Empson's response, quite simply, is that the mind takes pleasure in achieving a better, more conscious grasp of its own operations and hence that any doctrine - like that of his opponents - which prevents it from so doing is one with harmful consequences not only for our appreciation of poetry but also, by extension, for the conduct of our intellectual, moral, and everyday social lives. ${ }^{1}$

So much for the back-and-forth of this debate as it emerged in response to Empson's Seven Types and has continued to rumble on since then, as for instance in the later round of 'theorywars' provoked by deconstruction, post-structuralism, and other such dubious continental imports as viewed by the (mainly Anglophone) upholders of intuitive or common-sense wisdom. However it would over-simplify the issue to state it in quite these terms since, as anyone will know who has followed developments in French critical thought over the past three decades, things have moved on apace since the heyday of structuralism in its 'classic', i.e., intensely theoretical and (at least by its then-current lights) methodologically rigorous phase. The challenge to that erstwhile confident self-image came from various quarters, among them Derrida's deconstructive reading of Saussurean structural linguistics and Lévi-Strauss's structural anthropology. (See Derrida 1976; and Derrida 1978: 278-93.) It also took a lead from Roland Barthes' reflections - in The Pleasure of the Text and elsewhere - on that whole missing dimension of affective and erotic experience (plaisir and jouissance) which could not but elude the grim paternal law of a full-fledged structuralist approach, as adopted in some of his own earlier writings (Barthes 1976). Still it is hard to avoid the impression that Barthes' turn 'against theory' is one that not only draws intellectual sustenance from all those past encounters (with Saussure, Lacan, and Althusser among others) but also leaves room for a great deal of very subtle between-the-lines theoretical and speculative thought. (For further striking examples see Barthes 1975; Barthes1977 and Barthes 1977a.) In most respects no two critics could be more different than Empson and Barthes, the one a commonsensical, distinctly 'British' kind of rationalist with strong empiricist leanings who tended to excoriate literary theory (especially in its French manifestations) as so much intellectual hot air, the other (so to speak) a theorist malgré lui even his moments of intimate reflection on the erotics of reader-response. ${ }^{2}$ All the same they have at least this much in common: that they conceive the relationship between theory, analysis, and pleasure (or appreciation) as one that goes wrong - gives rise to much sterile debate - as soon as those activities are thought of as in any way separable one from another.

\section{2}

My main interest here - and my pretext for this detour via Empson and Barthes - is the recent emergence of similar debates with regard to the merits of musical analysis as a means of enhancing or (as some would have it) of obstructing our straightforward, intuitive grasp of what music has to offer by way of pleasurable experience. ${ }^{3}$ This analogy is itself rather less than straightforward for various historical, cultural, and discipline-specific reasons. One is the fact that music analysis was pretty well established as a modus operandi from the mid-19 $9^{\text {th }}$ century on, albeit in forms that would scarcely pass muster by present-day academic standards. appreciation of music - or adequate account of musical meaning and value - would need to respect its 'absolute' status and would hence do well to resist or discount any notion of programmatic content (Hanslick 1986). Such was the basic philosophical premise of what there For it was then that the idea emerged, most forcefully in Hanslick's writings, that any genuine

\footnotetext{
See various of the articles and reviews collected in Argufying 1987 for further arguments to this effect.

See Argufying 1987 for some of Empson's repeated fallings-out with 'theory' in its various forms.

See for instance Baker / Beach / Bernard 1977; Bergeron / Bohlman 1992; Cook / Everist 1999; Kramer 1995); Lochhead / Auner 2002; Solie 1993.
} 
after became a veritable item of faith for critics who professed to be concerned with the musical work 'itself', rather than with various (no doubt interesting but strictly extrinsic) aspects of its cultural background, psychological genesis, reception-history, and so forth.

Thus the trend toward ever more refined and sophisticated methods of formal-structural analysis is one that took hold very largely through the growth of academic musicology and its attendant division of intellectual labour between, on the one hand, positivistically-inclined music historians or sociologists and, on the other, theorist-critics with a strong autonomist bias. ${ }^{4}$ Its benchmark expression - for proponents and antagonists alike - was Schenker's ultra-formalist insistence on tracing every detail of a work's surface structure to some underlying generative theme or motif which then served as justification for the claim of structural coherence or 'organic' form..$^{5}$ Indeed this approach went so far as to assert that the ultimate aim of analysis was to derive the entire composition from the tonic triad (or root chord) in relation to which it could then be seen as a massive yet always homebound excursion through various thematic transformations, tonal departures, or long-drawn cadential and other such suspensive devices. To be sure this invites a number of objections, among them the familiar circularitycharge (to put it crudely: that analyst and work are engaged in a process of mutual reputationboosting) and the claim that such methods, Schenker's in particular, are reductionist to the point where all music is treated - absurdly - as a mere detour en route to restoring that primordial 'chord of nature'. ${ }^{6}$ Furthermore, suspicions have lately been raised that the origins of this approach were deeply bound up with a form of 'aesthetic ideology' which deployed metaphors of organic growth and development in the service of a cultural-nationalist creed with distinctly hegemonic, highly conservative and (some would say) proto-fascist inclinations. ${ }^{7}$ After all, Schenker took it as self-evident - a truth infallibly borne out by analysis - that the greatest works were those belonging to the mainstream Austro-German line of descent from Bach, through Haydn, Mozart and Beethoven, to Schubert and Brahms. This status had to do not only with their superior degree of thematic complexity and formal integration but also with their standing in just that kind of privileged lineal relationship, one that effectively transferred those values from the individual work - organically conceived - to a version of musical history likewise premised on organicist (i.e., strongly teleological) notions of predestined development and growth.

Whence, so the charge-sheet continues, Schenker's attitude of undisguised contempt for any. music - including, notoriously, that of Debussy - whose sensuous appeal, thematic elusiveness, or lack of 'structure' in the operative (Schenker-approved) sense rendered them resistant or opaque to analysis and thus placed them firmly beyond the canonical pale. Moreover, in hindsight, that attitude takes on a whole range of disturbing, even sinister overtones to the extent that it foreshadows those kinds of 'national aestheticism' - exemplified above all in the Wagner-cult and associated forms of Nazi cultural propaganda - which likewise entailed a demotion or suppression of other, so-called 'decadent' or 'degenerate' art (Lacoue-Labarthe / Nancy 1988). In short, there is a dangerous pseudo-logic that can easily lead from claims concerning the structural integrity or 'organic' character of certain works, via claims with regard to their intrinsic value thus defined and analytically revealed, to claims that such value is the sole prerogative of just those cultures - or just that singular, rightfully predominant culture - which brought them to birth. That Schenker is well known to have espoused political views very much in keeping with such musico-aesthetic values and predilections is yet further grist to the

\footnotetext{
See Kerman 1980; Kerman 1983; Kerman 1985; also Burnham 1996; Solie 1980.

See Schenker1973; Schenker 1979; also Beach 1983; Blasius 1996; Forte / Gilbert 1982); Narmour 1977; Siegel 1990; Treitler 1989; Yeston 1977.

See various entries under Notes 3, 4 and 5, above.

See for instance Goehr 1992; Korsyn 1993; Solie 1993; also - in a closely related vein - Man 1996; Lacoue-Labarthe / Nancy 1988.
} 
deconstructive mill of those present-day theorists - exponents of the 'New Musicology' - who have taken to denouncing the whole enterprise of 'analysis' as merely an expression of deeplaid ideological bias concealed behind a fake appearance of objectivity and rigour. (Notes 3 and 4.) Along with this, very often, goes a protest in the name of musical pleasure, enjoyment, or appreciation as against the kind of 'structural listening' enjoined by critics who assume - in typically 'analytic' style - that any hearing of a work which fails to perceive its long-term patterns of thematic transformation, motivic development, tonal progression, and so forth, is a hearing that manifestly fails to grasp its true significance and value. ${ }^{8}$

Such claims are by no means confined to analysts of a broadly orthodox, that is to say, for the most part academically-based and - by their own account - politically neutral persuasion. Indeed, the case for 'structural listening' is one that is put with great emphasis by Adorno since he considers it the only means by which music can effectively challenge - or be heard and understood to challenge - the kinds of uncritical, facile, or stereotyped response that otherwise typify every aspect of our social and cultural lives under the conditions of late commodity capitalism. (See especially Adorno 1973, 1982, 1997, 1998.) Thus, for him, it stands opposed to those forms of mass-media entertainment (such as music that lends itself readily to large-scale popular consumption) whose relentless promotion by the 'culture industry' is among the most effective agencies of social control, working as it does to repress or destroy any last remnant of the critical-emancipatory impulse (Adorno 1991). Hence Adorno's stark diagnosis of the trend toward 'regressive listening' which fails (or refuses) to engage with the long-term structural elements of musical form and contents itself solely with the kinds of enjoyment to be had from the standard fare of 'popular classics', or from favourite chunks of those works wrenched out of context so as to demand least effort of musical comprehension.

For many readers this just goes to show that Adorno, whatever his supposedly 'radical' (i.e., Marxist-influenced) ideas, was in fact an upholder of the cultural status quo and a defender of elitist values which were none the less so for his presenting them in the guise of a critical theory that proclaimed its opposition to every form of ideological conditioning. (See Briel / Kramer 2001; Cook D. 1996); Gibson / Rubin 2002; Paddison 1996.) As evidence of this they cite (among other things) his constant appeal to the canonical masterworks of Western musical tradition, his indiscriminate lumping-together of 'authentic' jazz with its tin-pan-alley derivatives, and (above all) his contempt for any music that didn't measure up to those classically-derived standards of formal integrity and good taste. The latter is a phrase that would scarcely have entered Adorno's critical lexicon but one - so his adversaries argue - that none the less captures the ethos and the tone of his writing once shorn of its pseudo-radical posturing. Thus Adorno's uneasy (not to say perverse) combination of an intensely formalist analytic approach with a critical agenda premised on emancipatory social and ethical values tends always to lean in the former direction, that is, toward an idea of 'structural listening' which effectively disqualifies any response that falls short of its own exacting criteria. What this amounts to is a further propping-up of 'the canon' and its hegemonic status, along with those increasingly refined analytical methods (albeit here bearing a Marxist inflection) which have served to maintain that status through various well-practised techniques of ideological co-option.

Such is at any rate the charge levelled against Adorno by a range of hostile commentators, from defenders of 'popular' music in its various forms, genres, or styles to critics who reject what they see as his Kantian (again strictly formalist) bias against any kind of aesthetic 'appreciation' that errs on the side of sensuous pleasure or downright hedonist indulgence. Amongst the New Musicologists one who has argued very forcefully to this effect is Rose Rosengard

8 For a range of views on musical analysis, its scope and limits, see Bent / Drabkin 1987; Cook 1989; Cook 1993; Cook 1996; Dempster / Brown 1990; Dunsby / Whittall 1988; Pople 1994. 
Subotnik in her book Deconstructive Variations (Subotnik 1996). Here she puts the case that any such emphasis on the virtues of 'structural listening' - whether by mainstream music analysts or by those, like Adorno, who claim to deploy it in the service of socio-cultural critique should be seen as just another standard device for shoring up those ideological values invested in the canon of received 'great' works. Subotnik finds nothing but high-brow cultural prejudice linked to professional self-interest in the notion that those works are intrinsically such as to demand an effort of sustained analytical attention, and that this provides not only a measure of their true greatness but a touchstone of musical perceptiveness and intelligence on the listener's part. Hence Adorno's attitude of sovereign contempt for those other, less elevated modes of response - ruthlessly exploited by the 'culture-industry' - which, so far from requiring a capacity for long-term structural grasp, encourage the listener to attend spasmodically, to pick out favourite passages for repeated hearing, and completely to ignore any aspects of musical form beyond the most basic, easily assimilated melodies and harmonic progressions. To his way of thinking, this marked the prevalence of a regressive, even infantile fixation on the kinds of purely sensuous pleasure - or desire for immediate gratification - that went along with other signs of a widespread malaise in the body politic, such as the demise of autonomous critical reflection among those who took their beliefs and values ready-made from mass media sources. Thus the stultification of collective intelligence went on apace, aided in no small part by the endless recycling of clichéd, stereotyped modes of listener-response whose effect - as with jazz, on Adorno's notoriously negative view of it - was to create an illusion of spontaneity which in fact worked to conceal its thoroughly banal and commodified character (Adorno 1991).

In an earlier book, Developing Variations, Subotnik had drawn quite extensively on Adorno's musical and sociological analyses, not least in making her case for a feminist and class-based critique of the dominant paradigms in academic musicology (Subotnik 1991). With the sequel, as I have said, she pretty much disowns this allegiance and comes out very strongly against his idea that 'structural listening' to works that invite or reward such attention is the sine qua non for any critical practice that would keep faith with music's now much diminished and yet - as Adorno strives to maintain - still latent emancipatory potential or occluded truthcontent (Adorno 1991a; Adorno 1991b; Adorno 1998a). On the contrary, she argues: this Adornian perspective is just another chapter in the long history of high-toned formalist and philosophic put-downs suffered by popular culture at the hands of those who would denigrate its pleasures as nothing more than frivolous distractions or ways of remaining blissfully well deceived. Thus Subotnik sees nothing wrong - nothing at all 'unmusical' - in the kinds of unfocused, intermittent, easily side-tracked, half-conscious, or free-associative listening that Adorno finds grimly symptomatic of our twilight cultural state. Still less does she go along with his distinctly Kantian mistrust of any pleasure in modes of aesthetic experience - such as the enjoyment of music at a sensuous level - that cannot be subject to formal analysis, or to treatment in conceptual (philosophic) terms.

To be sure, a central theme and motivating impulse in much of Adorno's work is the need to resist that totalising (potentially totalitarian) drive toward absolute conceptual mastery that tends always to repress or ignore the stubborn particularities of lived experience (Adorno 1997; Adorno 1974). Yet it is often hard to escape the impression that Adorno's own dialectical drive - albeit in the name of a 'negative dialectics' that strives to resist such closure - is itself so strong and conceptually hard-driven as to place that aim in some doubt. Thus his critics have a point when they remark on this tension in Adorno's thought between an overt dedication to saving the particular from the ravages of abstract generality and an approach that risks doing precisely the opposite through its relentless pursuit of dialectical arguments whose result - very 
often - is to force a procrustean either/or logic onto musical works and musico-historical developments. Such is, for instance, the doctrinaire juxtaposition of Schoenberg versus Stravinsky in Philosophy of New Music and the constant presumption in Adorno's writing that any musical 'appreciation' meriting the name must go by way of so intensive an analytical engagement as to place it quite beyond reach of any but the most refined and highly-trained musical intellects. So to this extent at least there is a certain justice in the charge often levelled against Adorno of his having drastically devalued the role of pleasure (or sensuous fulfilment) in our experience of music and, by the same token, over-rated the importance of analytic grasp - or 'structural listening' - as a measure of what such experience properly involves.

All the same this argument may be thought to have gone too far if it concludes that analysis has no place in our musical responses, or that pleasurable listening has nothing whatever to do with the kinds of longer-term structural awareness that analysts are expert in finding out. Thus Adorno was right to insist - as against Subotnik and others who attack his 'elitist' approach - that there is something intrinsically valuable about the kinds of listening (and the kinds of work) that find room for a perception of long-range tonal, thematic, and developmental structure as well as for the more immediate pleasures of short-term sensuous response. To adopt such a view is not merely, as some sociologists of culture would have it, an expression of class-prejudice or gender-bias encoded in a highly technical language (i.e., the discourse of present-day, post-Schenkerian music analysis) whose seeming objectivity and effort to avoid any taint of programmatic or affective content is precisely the mark of its ideological character. (See various entries under Notes 3, 4, 5 and 7; also Bourdieu 1984.) That is to say, borrowing a useful distinction from philosophy of science, interests of this sort may well play a role in the 'context of discovery' where music critics - and listeners bent upon increasing their stock of 'cultural capital' - are no doubt subject to all manner of social, professional, academic, psycho-biographical, and other such extraneous motivating factors. However they have no bearing on issues raised in the 'context of justification' where it is a matter of making good one's claims with respect to (say) structures of tonal development or motivic and thematic transformation. (See especially Reichenbach 1938.) For those claims are typically advanced with respect to certain agreed-upon standards - of evidence, precision, demonstrative warrant, sensitivity to context, and so forth - in consequence of which they can properly be held to stand on their merits and transcend any reductive sociological account.

Of course it will be said by opponents that these are just the sorts of self-confirming, purely circular and hence empirically vacuous criteria that typify the analytic enterprise, determined as it is to keep itself in business by producing ever more elaborate analyses which merely take for granted the superiority of music that suits its own preconceived values. Thus the two main prongs of this adversary case are, first, that such values apply only to a narrow, canonically privileged subset of musical works and practices, and second, that they are not so much 'there' to be discovered through objective analysis as projected onto those works through a strong disposition in favour of ideas like thematic development, organic form, structural complexity, etc. Hence Subotnik's later, more 'radical' position according to which there is something intrinsically suspect - ideologically compromised - about the whole business of music analysis, even where this takes the form (as in Adorno) of a project with overtly critical, progressive, and social-emancipatory aims.

\section{3}

These developments in recent, broadly 'deconstructive' music theory can be traced back to a influential 1983 essay by the critic Joseph Kerman, whose work up to then had combined an 
analytic with a cultural-historical approach and done so without any overt sense of a looming crisis in either discipline, or the relationship between them (Kerman 1980). The article ('How We Got Into Analysis, and How to Get Out') sought to put an end to this comfortable state of affairs by declaring the crisis already upon us and offering a diagnostic account of its symptoms and their cultural aetiology. Briefly stated, analysis as practised hitherto by mainstream musicologists was a product of that same 'aesthetic ideology' which literary theorists had long since recognised as a potent source of illusory notions - such as that of 'organic form' - whose extension into the wider (socio-cultural and political) domain was at best an unfortunate category-mistake and at worst a highly dangerous conflation of realms. (Notes 3 and 4.) It was just this delusion which had given rise to that particular strain of 'aestheticised' politics whose expressions ranged from the more overtly nationalist versions of German idealism and romanticism to Wagner's ideal of the Gesamtkunstwerk, or from Schenker's conception of musical form as growing out of certain germinal motifs to his likewise deeply organicist view of those same values as bearing out his claim for the superior quality of works in the Austro-German line of descent. Thus Kerman put the case that musicologists had yet to catch up with certain crucial developments in literary theory - chiefly of a French provenance - which had gone far toward deconstructing the kinds of ideological baggage that went along with the analytic programme, albeit (no doubt) unbeknownst to most of its practitioners. What the discipline needed was a healthy injection of 'theory', this latter equated by Kerman with a willingness to examine its own deep-laid, even (it might be) discipline-constitutive values, assumptions, and priorities. Only thus - by taking various leaves out of the deconstructionist book - might analysis shed that bad Schenkerian legacy of national-aestheticist thinking and learn to question those hegemonic notions (of form, unity, thematic integration, 'structural listening', and so forth) that presently exerted such a harmful grip on its working principles and practices.

What made the situation worse, according to Kerman, was the way that music analysis of this sort went along with an approach to musical history that was likewise in hock to certain outworn, nineteenth-century 'positivist' conceptions of scholarly method. Here also, musicologists proceeded as if their discipline could and should remain entirely untouched by those major developments in other fields - hermeneutics, critical historiography, narrative poetics, structuralism, post-structuralism, feminism, deconstruction - whose deployment elsewhere had exerted such a powerful transformative impact. Once they started taking stock of such developments, Kerman surmised, they would find themselves impelled not only to re-think the methodological foundations of their work but also to raise serious doubts with regard to its ideological complicities, not least as concerned that entente cordiale - rather nicely exemplified, one is tempted to remark, in Kerman's own previous work - between music history and music analysis as currently practised. (See for instance Kerman 1962, 1967, 1981.) In particular they would have to ask whether the very fact of this peaceful coexistence might not indicate a symptomatic failure or refusal to examine that complex, essentially contested, and ideologically charged relationship. Even a cursory acquaintance with the writings of a literary theorist like Paul de Man would suffice to show that they had come nowhere near thinking it through with the requisite degree of self-critical awareness. (See Man 1996; also Man 1983, 1984 and Man 1986.) And it would then become apparent, so Kerman claimed, that musicology in both departments was in urgent need of opening its doors to the kinds of thinking that had brought such benefits - as he definitely took them to be - when applied in those other, more advanced and speculative regions of debate.

When Kerman's essay first appeared he could plausibly strike the heroic tone of one crying in the academic wilderness, or of Milton's archangel Abdiel, 'alone against the forces of 
night'. Now, twenty years on, his plea for musicologists to broaden their theoretical horizons and absorb the lessons of deconstruction and other such cutting-edge developments is apt to sound distinctly old-hat or more like a fairly conservative prognosis of developments already under way. For it can hardly escape the notice of anyone who browses through the current music journals, bibliographies, or publishers' catalogues that musicology has taken the 'deconstructive turn' with a vengeance, and that 'theory' has triumphed (or at any rate made territorial inroads) beyond Kerman's wildest dreams. (See Notes 3, 4 and 7.) Indeed it wouldn't surprise me if he was less than happy about the extent to which - in certain quarters at least his proposals have been taken on board and the rapidity with which they have become something very like an orthodox creed. Thus there is now a minor industry of 'deconstructive' musicology devoted to dismantling both the discourse of mainstream analysis - especially any talk of 'organic form' - and, beyond that, the habits of structural listening or long-term musical-cognitive uptake which are thought to fall in with just such ideologically complicitous notions.

Of these debates perhaps the most revealing is that between Jonathan Dunsby and Alan Street on the topic of Brahms' late piano Fantasies, Op. 116. In this sequence of pieces - most often thought of as loosely related in terms of style, mood, and general character - Dunsby purports to hear (and to demonstrate by detailed analysis) a whole range of thematic crossconnections and subtle inter-movement unifying features (Dunsby 1983; also Dunsby 1981). To which Street responds that Dunsby's desire to 'discover' such features in the music is a projection of his own analytic (and ideologically-driven) belief that a great work must, by very definition, manifest them in some degree and that the greatness of these particular pieces can be brought out all the more convincingly by showing their unity to transcend the limits of their surface, episodic or suite-like form (Street 1989). In the process Street draws upon a good many theoretical sources, among them de Man's deconstructive readings of numerous texts - philosophical, literary, literary-critical - which he (de Man) takes to exhibit all the signs of their having been seduced by that form of aesthetic ideology which consists in 'confusing linguistic with natural reality' (Man 1986: 11). Such is, for instance, the widespread idea among literary critics of otherwise diverse persuasion that poetic language somehow has the power not merely to describe, evoke, or represent features of the natural world but (through devices like metaphor and symbol) to render them with all the sensuous vividness that belongs to our various modes of perceptual experience. This elementary confusion - as de Man thinks it - gives rise to the further, more dangerous since ideologically charged error of attributing characteristics to language which are then metaphorically extended beyond the aesthetic domain to concepts of language, culture, and (ultimately) the nation-state as expressions of a likewise natural process of organic development and growth. (See Man 1983, 1984, 1986.)

Hence, to repeat, his constant emphasis on the need for close attention to those crucial passages in certain exemplary thinkers - pre-eminently Rousseau and Kant - which show how they managed to avoid such temptations by maintaining the highest degree of critical vigilance, but also how their texts were later subject to various kinds of 'aberrant', ideologically driven misreading. It is this deManian imperative that Street and other deconstructive musicologists have in mind when they counsel an attitude of principled suspicion toward any method, technique, or practice of analysis that rests its claims on such illusory (and, in their view, politically retrograde) notions as those of organic form or long-range structural unity. To which end they typically set about showing - as in Street's altercation with Dunsby - that the analyst's text itself contains certain symptomatic blind-spots or unnoticed and questionable turns of metaphor that unwittingly reveal its deep involvement with just such ideological values. Only thus, so the argument runs, can music criticism at last catch up with those developments in lit- 
erary theory that have long since disposed of an organicist aesthetic, like that of the 'old' New Criticism, whose talk was of seemingly disruptive or 'non-totalising' figures such as ambiguity, irony, or paradox but whose overriding aim was to present the poem as a 'verbal icon' wherein such tensions were finally resolved or reconciled. (See especially Brooks 1947 and Wimsatt 1954.) Here again de Man is taken to provide an object-lesson in the deconstructive reading of texts that are thereby forced to reveal their ideological hand (Man 1983).

To be sure, Street brings some strong theoretical arguments to bear on the discourse of mainstream music analysis, arguments which make a plausible case for viewing it as heavily mortgaged to just those values that de Man finds complicit with the workings of aesthetic ideology. His proposed remedy - again taking a lead from de Man - is to read that discourse against the grain by refusing to endorse the privilege it attaches to tropes such as metaphor and symbol, that is to say, 'totalising' tropes which reliably facilitate the passage from particular details of the literary work to a conception of that work as exhibiting an overall, transcendent unity of theme and idea (Man 1983: 187-208; also Man 1979). Such a reading would take as its principal aim the demonstration that metaphors self-deconstruct into chains of metonymic displacement, substitution, or surreptitious part-for-whole transference, and moreover that the symbolist notion of organic form - as it figures (expressly or implicitly) in so many versions of aesthetic ideology - can likewise be shown to fall back upon textual mechanisms whose structure is that of allegory, rather than symbol. This is not the place for a full-scale exposition of the various texts (in particular his readings of Rousseau, Nietzsche, and Proust) where these claims are tested to the utmost degree of hard-pressed rhetorical analysis, not to mention - as some might add - the utmost limits of readerly endurance. (Man 1979 and Kerman 1962; Kerman 1967; Kerman 1981; also Gasché 1998 and Norris 988.) Suffice it to say that metonymy stands as the trope whose prosaic, down-earth, literal, non-'totalising' character allows it most effectively to counter the claims of metaphor, that is, to remind us how the language of metaphor unravels or self-deconstructs into chains of contingently-related metonymic detail that stubbornly resist assimilation to the realm of metaphorical quasi-transcendence. So likewise in the case of allegory versus symbol: where symbolist readings typically indulge in an over-willingness to take such claims at face value (that is, as achieving a consummate union between subject and object, mind and nature, time-bound or mortal existence and a realm of transcendent eternal truths) allegorical readings typically insist on the temporal character of all understanding and hence the sheer impossibility that language might attain that wished-for condition.

Thus allegory is not so much a well-defined literary genre - including such works as The Faerie Queene, Pilgrim's Progress, or Animal Farm - but a certain mode of critically reflective and rhetorically alert close-reading which holds out against the seductive blandishments of symbolist thought. And again: metonymy is not (as often supposed) just a kind of poor relation to metaphor, that is to say, a trope whose mundane character - forming as it does the stock-in-trade of most non-'literary', e.g., journalistic or workaday prose - invites unfavourable comparison with the creative or world-disclosive potential of metaphoric language. Rather, on de Man's account, it is a trope that can be shown to inhabit that language and indeed to constitute the underlying structure of every (supposed) metaphor. Thus metonymy and allegory turn out to subvert the traditional order of priorities and the high claims vested in metaphor and symbol as somehow granting access to truths beyond the grasp of commonplace, prosaic understanding. So to read allegorically and with an eye to metonymic details that resist or obstruct the suasive power of other, more seductive metaphorical-symbolist readings is also to engage in a form of Ideologiekritik with large implications for our thinking about issues of 
ethics and politics. This is why, as de Man provocatively puts it with an eye on his Marxist or cultural-materialist critics, "[t]hose who reproach literary theory for being oblivious to social and historical (that is to say ideological) reality are merely stating their fear at having their own ideological mystifications exposed by the tool they are trying to discredit. They are, in short, very poor readers of Marx's German Ideology' (Man 1986: 11).

However there is a problem - I want to suggest - with attempts to transfer this approach from the realm of literary criticism to the domain of musical analysis where any claims advanced on behalf of this or that 'reading' must surely concede a certain priority to the perceptual or phenomenological experience of music. That is to say, the fact that many verbal analyses (like Dunsby on the Brahms Fantasies) can be shown to exhibit a strong attachment to organicist models or metaphors is no proof that they are distorting or misrepresenting the music to ideological ends, or indeed that those metaphors don't capture something intrinsic to the well-equipped listener's pleasure and appreciation. Where de Man's arguments get a hold is through the undisputed truth - undisputed by all save die-hard adherents to a Cratylist doctrine of linguistic mimeticism - that language is a system of purely conventional ('arbitrary') relations between signifiers and signifieds, or again (in Saussurean structuralist parlance) of 'differences without positive terms' (Saussure 1974). Thus apart from such oddities as onomatopoeia or cases, as with poetry, where the sound very often in some way 'echoes the sense' it is a clearly a fallacy - and one subjected to withering critical scrutiny by de Man - to suppose that verbal language can somehow partake of the 'natural' reality that makes up its field of reference. In de Man's somewhat tortuous phrasing: '[t]he phenomenality of the signifier, as sound, is unquestionably involved in the correspondence between the name and the thing named, but the link, the relationship between word and thing, is not phenomenal, but conventional' (Man 1986: 10). And again: '[l]iterature is fiction not because it somehow refuses to acknowledge "reality", but because it is not a priori certain that language functions according to principles which are those, or which are like those, of the phenomenal world' (Man 1986: 11). However it is far from clear that this argument might plausibly be carried across from the textual-linguistic to the musical domain, or - what is chiefly at issue here - from deconstructive readings of the discourse of music analysis to claims concerning our perceptual or phenomenological experience of music. For these latter have to do with modalities of jointly sensuous and cognitive (i.e., conceptually informed) perception which cannot be treated as mere figments of 'aesthetic ideology', or as symptoms of the Cratylist delusion that naively conflates linguistic structures with the forms or processes pertaining to natural phenomena.

This is why, as I have said, theorists should not too hastily reject the idea of 'structural listening' - whether advanced by mainstream analysts or by a critical dialectician like Adorno as just a product of those old elitist values that serve to shore up both the canon of established 'great works' and the business of academic musicology. For it is simply not the case - or, at least, not simply the case - that such listening (and the pleasure afforded by it) is confined to some few professional adepts and leisured cognoscenti who have access to the specialist books, journals, or high-brow broadcast media whereby these values are diffused, along with the kinds of analytical approach that bolster their cultural standing. Rather, what is revealed by a good, sharp-eared, intelligent, and (above all) intuitively valid essay in musical analysis is what the listener is able to hear for herself through close and sustained attention to the music although perhaps, without having read that essay, unable to articulate in verbal form with such point and precision. This is not to deny - far from it - that analysis can bring out aspects of a work, from subtleties of detail to aspects of long-range structure, that the listener might well have missed up to now or been 'aware' of only in so vague or unfocused a way as scarcely to 
count as conscious recognition. All the same, such analytically arrived-at insights will themselves scarcely count as such unless they chime with something in the listener's intuitive musical response which then serves as a measure of just how far the analyst has managed to hit on the right (i.e., perceptually salient) aspects of detail and structure.

A rough but useful analogy here would be that of the grammarian whose theories of what constitutes a well-formed or ill-formed sentence, a normal or deviant active-passive transformation, and so forth, must always be checked against the verdicts of a competent native speaker if they are to claim any kind of descriptive validity. Indeed, one branch of recent, postSchenkerian analysis that brings out this point very clearly is the transformational-generative model proposed by Lerdahl and Jackendorff, where listener-response must surely be a crucial test in evaluating some particular claim with regard to what's really going on the process of depth-to-surface tonal and thematic transformation (Lerdahl / Jackendoff 1983). Nevertheless, here as with other kinds of analysis, one should also allow for the extent to which musical perceptions can be further, more deeply or even creatively informed by the kinds of consciousness-raising structural insight that such theories seek to provide. It is this possibility that seems to be barred - ruled out on ideological grounds - by those among the New Musicologists who see nothing but a rearguard defence of elitist cultural values in the value attached to 'structural listening' as against the claims of straightforward, uncomplicated musical pleasure. That is say, these theorists may be indulging a form of inverted cultural snobbery whereby it is assumed that complex, long-range or sophisticated modes of musical appreciation are ipso facto beyond reach of a popular audience while other, more immediate forms of gratification - those pleasures to be had from 'music in the moment' - are the sort that do possess a widespread appeal and should therefore be defended against their detractors by anyone with a welldeveloped social and political conscience. However, this risks selling everyone short: the analysts (whose efforts are written off as mere products of aesthetic ideology), the 'structural listeners' (who are, after all, perfectly entitled to their own kinds of satisfaction), the creators and performers of 'popular' music (which itself covers a huge range in terms of musical complexity and value), and - not least - the mass-audience whom these theorists effectively rule offbounds when it comes to other, more demanding (and perhaps more musically rewarding) modes of listener-involvement.

The phrase 'music in the moment', as used above, is actually the title of a book by Jerrold Levinson which raises some of these issues from a different but related philosophical angle (Levinson 1997). Levinson agrees with the New Musicologists that analysis goes wrong by attaching such inordinate value to long-range structural aspects of music, as distinct from those far more vivid, direct, and readily appreciated 'momentary' features - accessible to short-term memory - which constitute the listener's chief source of genuine (rather than abstract or hypercultivated) pleasure. However his reasons for taking this view have less to do with any programme of socio-cultural-political critique than with certain lessons which he thinks should be drawn from phenomenological or cognitive-psychological reflection on the scope and limits of perceptual responses to music. In brief, these are that our attention-span is more restricted than the analysts suppose, that our powers of retentive grasp are confined to just a short stretch of time, and moreover that even when we know a work well - and should thus (on the analytic view) have a long-term anticipatory awareness of developments yet to come - we are still listening very much 'in the moment' and largely oblivious of them unless at a level of abstraction far removed from the actual experience of music. Thus Levinson - like Subotnik but on different grounds - takes a pretty dim view of any analytic approach whose effect is to promote the virtues of structural listening and thereby devalue the pleasures that accrue (more precise- 
ly: that occur in rapid succession) if one lends an ear more attuned to those short-term modes of perceptual experience.

He is challenged on this by another philosopher, Peter Kivy, who not only disagrees strongly with Levinson concerning those tight limits on the human capacity for long-range musical perception but states his disagreement in unusually forceful and passionate terms (Kivy 2001). For Kivy - and also, I should say, for myself as a matter of personal as well as theoretical conviction - it is a truth borne out on many occasions over the years that one's appreciation of music can be greatly enhanced by the reading of perceptive analyses which conduce to a heightened, more adequate grasp of large-scale structural attributes far beyond the sadly impoverished range of Levinson's amnesiac listener. Indeed, I would suggest that Levinson's low estimation of our normal capacities in this respect is such as to imply a likewise low estimation of the standards that music should meet - standards of inventiveness, thematic interest, sustained harmonic development, tonal progression, rhythmic subtlety, and so forth - if it is to offer the kinds of reward that come with repeated and properly attentive listening. Thus anyone whose powers of retentive or anticipatory awareness were really as limited as Levinson decrees would be very much at home with the compositions of Philip Glass, Michael Nyman, (the later) Arvo Part, John Tavener, and other such exponents of a minimalist style which relies on the constant repetition of banal and easily recognised themes with just enough in the way of undemanding harmonic or rhythmic variation to jog the hearer into semi-consciousness once in a while. Or again, they would be equipped to appreciate a large amount of bottom-drawer baroque music which also involves an absolute minimum of 'structural listening' in so far as it rehearses a predictable range of well-worn stylistic and formal techniques with only minor departures from the expectations raised by an acquaintance with the relevant generic norms. However their responses would fall drastically short when it came (say) to Bach, to Vivaldi's more inventive works, to those other baroque composers (or individual works) that rose above the stock-in-trade conventions of the time, or to all but the earliest of Haydn's quartets and symphonies. Still less could they come close to a real appreciation - as distinct from a piecemeal enjoyment - of mature Mozart, late Beethoven, Schubert, Brahms, or indeed any music where the interplay set up between expectations and the thwarting or subtle disrupting of those same expectations is a chief source of sensory-perceptual pleasure and intellectual stimulus alike.

\section{4}

Hence, as I have said, the taint of inverted snobbery that hangs around the discourse of professional musicologists, theorists, and philosophers who claim to be speaking on behalf of the common listener when they attack such 'elitist' values, but whose argument can just as plausibly be read as an attack on the overweening pretensions of any listener - 'common' or not - with a taste for more developed or sophisticated modes of musical response. This revolt against analysis (or structural listening) in the name of, ostensibly, more direct and non-exclusive musical pleasures is one that has other dubious results. They include the return - by various exponents of the 'New Musicology' - to an oddly reductive and literalist notion of programmatic content (often reminiscent of the old 'life-and-times' approach) motivated partly by their anti-formalist bias and partly by the concomitant desire to bring music and music criticism back down to earth through an account of their class-based, gender-inflected, or ideologically 'constructed' character.

Here again Kivy has some sharp observations to make, especially concerning this current trend in its cruder, more doctrinaire manifestations. Thus there is, to say the least, something 
caricatural about hearing the pent-up dynamism in the first-movement development section of Beethoven's Eroica Symphony as an expression (or unwittingly blatant confession) of the thwarted rapist's urgent drive for sexual mastery (McClary 1991; also McClary 2000). Nor does it conduce very much to our better musical understanding to be told that the contrast between 'masculine' first subject and 'feminine' second subject in the opening movement of Tchaikovski's Fifth represents a desperate struggle in the composer's mind between sociallyenforced denial and deeply-felt acceptance of his own homosexual desires (McClary 1991). Admittedly these are extreme cases and one could instance other readings of musical works with a view to their (often ambivalent) psychosexual or ideological sub-text which involve nothing like so crassly reductive an approach. Nevertheless, even at its most sensitive and methodologically refined, this approach tends push the anti-formalist reaction to a point where it risks falling back into a harmful confusion of life and work. That is to say, it shows many signs of regressing to a standpoint strangely unconversant with Adorno's far subtler, more musically responsive yet also - quite compatible with this - more historically and socio-politically informed mode of analytic discourse. Thus when theorists like Subotnik claim to have thought their way through and beyond Adorno's influence - and to have done so, moreover, by an outright rejection of ideas such as that of 'structural listening' - one is entitled to question whether this constitutes any kind of intellectual advance or indeed (as advertised) a return to the values of genuine musical enjoyment as opposed to the abstract rigours of formal analysis.

Kivy makes the point rather neatly when he invites us to entertain a thought-experiment regarding the claims of programmatic or 'content'-based interpretation on the one hand and formalist or structurally-oriented approaches on the other (Kivy 2001). Consider, he suggests, the case of three accomplished but in varying degrees untypical appreciators of the arts - Peter, Paul and Mary - whose aesthetic responses each have a certain distinctive or peculiar feature. Peter is an enthusiast for German poetry who possesses an exceptionally acute ear for the phonetic qualities (rhyme-schemes, patterns of alliteration, or ways of playing off of metrical structure against natural speech-rhythms) to be found in Goethe, Hölderlin, and Rilke but who doesn't understand a word of German and thus savours those qualities with not the least grasp of how the sound echoes or subtly qualifies the sense. Paul is a visual-art connoisseur who has developed an ultra-fine appreciation of various formal attributes - of balance, contrast, structural proportion, perspectival effects, the interplay of light and shade, etc. - but who suffers from a curious kind of aspect-blindness that prevents him from perceiving the representational content of figurative paintings. Then there is Mary, a music-lover, who doesn't merely 'know' (in the abstract) all that abstract stuff about sonata-form, first and second subjects, developing variation, progressive tonality, and so forth but who truly understands, enjoys, and appreciates what music has to offer on just those descriptive or analytical terms. That is to say, she is a 'formalist' or adept of 'structural listening' but one to whom this comes very much as second nature and for whom such descriptions genuinely chime with her first-hand, intuitive and passionately engaged experience of music. What puts her in the company of Peter and Paul, for the purposes of Kivy's thought-experiment, is that Mary just doesn't get it when people talk about the programmatic content of works like the Eroica Symphony, or Haydn's Creation, or Richard Strauss's Ein Heldenleben, or Elgar's Falstaff, or indeed - perhaps more controversially - some of Bach's (to most ears) very striking mimetic devices in his settings of religious texts. (These are my examples, not Kivy's.) Thus Mary might be counted a fellow-sufferer in so far as she seems to be missing out on something that other, 'normally' equipped listeners can be expected to hear in the music and which presumably heightens their appreciative grasp of its content, meaning, and value. 
However it is just Kivy's point that, despite appearances, these cases are in fact very different. Thus whereas Peter can scarcely be said to 'appreciate' German poetry at all, and whereas Paul must likewise be considered blind to something intrinsic to the nature of figurative art, Mary cannot rightly be said to lack anything essential to the proper understanding or appreciative grasp of music. Perhaps it may be said - by anti-formalists of various persuasion - that she does in fact miss out on certain kinds of pleasure enjoyed by other listeners, i.e., those receptive or responsive to such elements of programmatic content. However, so Kivy maintains, this is surely not a failure of musical intelligence, perception, or involvement on her part, nor a deafness to anything intrinsically 'there' in the work, but rather a non-dependence on ways of listening that by very definition have at most an extraneous, secondary, or strictly inessential role to play. More than that: in cases where the listener - or (possibly) the music does rely heavily on attributions of programmatic content then this gives reason to suppose that one or other falls short of what the best, that is to say, most musically rewarding since least secondary-response-dependent works have to offer.

Now of course this will strike the opponent (whether old-style defender of content-based musical interpretation or new-style advocate of deconstructive, Foucauldian, feminist, neoMarxist or kindred forms of Ideologiekritik) as just another, albeit neatly-turned statement of the formalist case and hence as subject to the same charges of inherent circularity or empty selfconfirmation. Indeed, it will no doubt stand accused of reinforcing that potent strain of 'aesthetic ideology' - transposed into the likewise highly suspect notion of 'structural listening' which music theorists have been quick to take up from de Man's later writings. All the same, as I have said, such accusations run the risk of ignoring some pertinent (even some ideologically crucial) distinctions, among them that between the kinds of deeply organicist, methodologically doctrinaire, and often quite explicitly chauvinist formalism exemplified by Schenker and those other varieties of analysis - whatever their particular problems or shortcomings - that hardly conform to this stereotype. Thus Adorno's work provides one striking example of an expressly analytic approach (and a corresponding emphasis on the virtues of structural awareness) conjoined with a range of cultural, historical, and - not least - philosophical reflections on the complex dialectical relationship between music and its social contexts of production and reception. (See Adorno 1973, 1982, 1991, 1991a, 1991b, 1997, 1998, 1998a.) But there are, and for quite a while have been, plenty of other, less elaborately theorised instances of music criticism that manages to heal - or at any rate to bridge for its own specific purposes - the rift that Kerman lamented between the discourse of music analysis and those wider contexts. Here I am thinking especially of Charles Rosen's writings, where a singular depth and acuity of musical perception goes along with a detailed scholarly knowledge of the relevant socio-cultural background and also a keenly intelligent sense of how debates in other areas (historiography, narrative theory, poetics, hermeneutics, and so forth) may help toward a better, more appreciative understanding. (See for instance Rosen 1975, 1976, 1996, 2000.) I would also mention among my own favourites - the wonderfully perceptive study of Ravel by Vladimir Jankélevitch, a critic whose other chief interests (in phenomenology, ethics, the philosophy of time, and irony) can be seen to inform his responses to the music in numerous subtle and revealing ways (Jankélevitch 1951, 1959).

So I am inclined to disagree with Kerman as regards his 1982 diagnosis and to suggest that things were in fact nowhere near as bad with the then-current state of academic musicology as he made out. Moreover, as implied by the above comparisons, it strikes me that Rosen is justified in claiming that a good deal of work produced by its subsequent, theory-led and sociologically-minded debunkers must be found to fall far short of the insights delivered by intelli- 
gent, context-sensitive analysis (Rosen 1994). That is to say, there is something distinctly wrongheaded about the notion that these approaches cannot go together, that a penchant for analysis must entail an attitude of downright indifference to socio-historical concerns and hence a complicity with dominant ideological values, or again - conversely - that a critical engagement with those same concerns and values will inevitably lead one to reject 'analysis' and all its works. On the contrary, I have argued: not only can and do they sometimes go very nicely together but it is also the case that neither approach can come close to an adequate understanding of music without those insights and conceptual resources provided by the other. This is one issue where literary theory might offer a useful lead, not so much in its more extreme (e.g., purist deconstructive or cultural-materialist) strains but more through its effort, over the past few decades, to achieve a synthesis or working balance between the formalist/structuralist imperative to analyse texts in strictly synchronic terms and the kinds of diachronic, historically-based approach enjoined by Marxists, sociologists of literature, and others of a seemingly opposite persuasion. (See especially Lodge 1977.) Thus, as Roland Barthes once wrote in a cryptic but typically pregnant passage, 'while a little formalism turns one away from history, a lot of formalism turns one back to it' (Barthes 1984: 186). At any rate there is more to be gained in this way, from the viewpoint of a critical musicology, than by following other doctrinally committed literary theorists to the point of an ultimate stand-off or breakdown of communication between the interests of analysis or 'structural listening' and the interests of historicallyinformed commentary.

The same applies - so I have argued - to that other false antinomy between music as an object of analysis and music as a source of pleasure. What we need to do here is triangulate and see that there is pleasure to be taken not only in the process or activity of formal/structural understanding but also in the kinds of appreciative benefit brought by a knowledge of music in its cultural-historical context. This might seem at odds with my general endorsement of Kivy's case as regards the primacy of formal attributes - and our ability to perceive or apprehend them - over any such merely 'extraneous' concerns. However one can take his argument on board (i.e., the primacy-thesis as a matter of aesthetic principle) without concluding that those latter sorts of knowledge or interest are therefore to be counted strictly irrelevant to musical experience, properly so called. There is support for this more accommodating version of the thesis from a range of disciplinary quarters, among them that of cognitive psychology where recent debate has often turned on the extent to which our various mental capacities should be thought of as 'encapsulated' or 'hard-wired'. That is to say, it is the issue as to just how far - if at all - they involve the operation of relatively discrete, self-contained, or (in the jargon) 'cognitively impervious' modules which carry out their multiple specialised functions with little or no input from other, more global or widely distributed modes of cognitive processing.

Jerry Fodor is the best-known defender of the 'strong'-modularity thesis according to which this applies to quite a range of otherwise diverse mental functions (Fodor 1976, 1983, 1989). These would include our everyday syntactic competence as language-users (here taking a lead from Chomsky's work in transformational-generative grammar) and also types of behaviour like the 'fight-or-flight' response - which may well have required a complex but rapid and unthinking, i.e., highly 'encapsulated' cognitive mechanism so as to facilitate species survival. However Fodor has lately shown signs of softening that line, at least in so far as he now sees intractable problems with the strong thesis when it comes to offering some plausible account of how we manage to perform high-level, complex, and inherently hard-to-formalise mental tasks - such as abduction, or inference to the best explanation - which must involve drawing 
on a wide range of background knowledge, much of it tacit or below the threshold of conscious awareness (Fodor 2000). This also has a bearing on our thought about music, as Mark DeBellis has argued in a recent book on cognitive-psychological aspects of the dispute between formalism (or 'structural listening') and its various detractors (DeBellis 1995). In brief, he puts the case that our musical responses cannot be strongly modular since they are clearly affected - most often in positive or experience-enhancing ways - not only by our reading of perceptive musical analyses but also, if to less striking effect, by our knowledge of relevant historical and socio-cultural background information. That such knowledge indeed belongs to the background, rather than the foreground where analysis has a more significant role to play, is a main plank in DeBellis's argument for the conceptually-informed nature of musical understanding and hence - in cognitive-psychological terms - its 'permeability' by the kinds of knowledge conveyed by sharp-eared analysts or structural listeners. All the same, it is hard to see how a principled distinction could be drawn so as to hold the formalist line between one and the other sorts of musical consciousness-raising, i.e., that which results from acquaintance with 'genuine' analytic insights and that which contingently accrues through exposure to some more-or-less 'relevant' piece of musico-historical information.

Thus DeBellis, like Kivy, makes a strong case for the merits of analysis as an active, integral, even transformative component of our musical experience rather than - as the current debunkers would have it - a discourse whose deeply ideological character is signalled by its sheer remoteness from such experience as well as its commitment to suspect values like those of thematic development, structural coherence, or (worst of all!) organic form. On the other hand their arguments also leave room for the intuitive conviction of many listeners, not all of them by any means naïve or musically illiterate, that knowledge of a work's historical context and even of certain psycho-biographical factors can often have a more-than-anecdotal bearing on the listener's musical experience. This it may well be true - as DeBellis maintains - that such experience, though grounded to some extent in a 'modular' capacity of musical response, nevertheless draws widely on other cognitive resources including that of analytically informed structural listening. But then there seems no compelling reason (formalist prejudice apart) to reject the idea that information of other sorts might play a broadly comparable role, albeit subject to the twin condition of (1) its demonstrable relevance to the work or passage in hand, and (2) the possibility of bringing out that relevance through an adequately detailed musical analysis in some shape or form. The chief problem with recent debate is that it has managed to create this artificially induced dilemma between a typecast 'formalism' wholly bereft of substantive historical or socio-cultural content and a likewise typecast 'reductionist' approach in the latter vein. Moreover, both have tended - through a kind of Newtonian equal-and-opposite-reaction principle - to adopt increasingly doctrinaire stances on the main points at issue and thereby confirm their opponents' worst suspicions.

\section{5}

If deconstructive musicologists want to break out of this dead-end predicament then they might take a second (or maybe a first) look at Derrida's essay 'Parergon', where he reflects with extraordinary tact, subtlety, and insight on the problems raised by Kant's formalist aesthetic (Derrida 1987: 15-147). What emerges from Derrida's reading of the Third Critique is a series of deep-laid aporias - conflicts, dilemmas, moments of strictly unresolvable impasse - having to do with the Kantian insistence on formal autonomy as an absolute requirement of art and aesthetic disinterest as the absolute condition for appreciating art (or natural beauty) as a matter of purely contemplative, i.e., non-instrumental pleasure (Kant 1978). Thus Kant is constantly 
obliged, by the logic of his own argument, to posit a range of de jure distinctions - as between form and content, 'free' and 'adherent' beauty, intrinsic and extrinsic attributes, 'determinate' and 'indeterminate' modes of judgement - which can be shown to self-deconstruct through the impossibility of holding them firmly in place. That is to say, the entire conceptual structure of this work - along with its crucial justificatory role vis-à-vis certain epistemological and ethical issues that were left unresolved in the previous two Critiques - turns out to depend upon the use of arguments, examples, metaphors, and analogies that are strictly indispensable to Kant's case yet which complicate the logic of that case beyond its power fully to determine or control.

Such is what Derrida describes as the 'parergonal' character of Kant's reasoning (from the Greek 'parergon' = 'frame', 'border', or 'that which surrounds, encloses, or sets off a work whilst not an integral part of it'). 'Parergonality' thus takes its place as another in the sequence of deviant, non-classical, or paraconsistent logics that Derrida first broached in his readings of 'supplementarity' in Rousseau, the pharmakon in Plato, différance in Husserl, and 'iterability' in the discourse of Austinian speech-act theory. (See Derrida 1987, 1976, 1980, 1982, 1989; also Norris 2003.) With Kant it emerges in some obvious ways, as for instance in his strange, surely untenable case for excluding from aesthetic consideration (i.e., from the domain of artistic form, properly so called) such 'parergonal' features as the drapery on statues, the colonnades of palaces, the flying buttresses or other 'merely' functional outworks that support gothic cathedrals, and so forth. However it also causes problems for his cardinal distinction between the realms of determinate and indeterminate judgement, or of knowledge (where sensuous intuitions are somehow 'brought under' adequate concepts) and aesthetic experience (where such concepts cannot apply since there would then be no room for that free and harmonious interplay of the faculties which signifies our appreciation of the beautiful). What these difficulties all come down to is the fact that any such Kantian attempt to 'frame' or delimit the proper sphere of aesthetic judgement will always run up against problems, aporias, or counterinstances that make it strictly impossible to decide whether some feature should be counted 'intrinsic' or 'extrinsic' to the artwork or our experience of it.

Thus - to take the most obvious and literal case - the frame around a painting would seem parergonal by very definition, yet can scarcely be held to have no effect on our appreciation of the work, since the right choice of frame sets it off to best advantage while the wrong choice may detract from its aesthetic appeal. And things become more complicated still if one considers how far - or by what kind of a priori aesthetic jurisdiction - the frame can serve as an impermeable border between that which properly belongs inside it (i.e., the painting) and that which exists altogether outside its aesthetically privileged space, such as the wall on which it is hung, the other paintings that surround it, or any number of supposedly irrelevant 'background' factors. For here again it is only in deference to certain Kantian formalist distinctions - like those between intrinsic and extrinsic attributes, or 'free' and 'adherent' beauty - that we might feel impelled to maintain what is otherwise (as Derrida's reading brings out) a deeply problematical doctrine. Moreover, this difficulty goes yet deeper since it affects Kant's argument concerning the uniquely contemplative, disinterested, non-instrumental (and hence non-conceptual) character of aesthetic experience. For if this were indeed the case - if concepts (e.g., philosophical concepts) were wholly extrinsic to our appreciation of art - then that experience could in no way be influenced, for better or worse, by our acquaintance with Kant's Third Critique or any other work of criticism, theory, analysis, or aesthetic philosophy. One only has to state the issue in these terms in order to see how implausible is that position and how pointedly Derrida's reading engages with the aporias not only of Kantian aesthetics but of Kant's entire critical project. 
Still it would be wrong - a gross misreading of Derrida's essay - to conclude that this puts him firmly on the side of those (at present a large company of sociologists, cultural theorists, postmodernists, and adepts of the New Musicology) who reject not only such formalist ideas as aesthetic autonomy or intrinsic value but also the entire discourse of post-Kantian aesthetics as merely the expression of a dominant bourgeois ideology passing itself off as the pure, disinterested judgement of taste. (Bourdieu 1984; See especially Bourdieu; also - for some arguments to contrary effect - Norris 2000.) For this is to ignore his repeated point: that such values are deeply intertwined with the wider, i.e., the ethical and socio-political project of enlightened thought, and hence cannot (or should not) be renounced whatever the abuses to which they have subject and the various ideological admixtures or impurities that have always gone along with them. (In this connection, see Derrida 1983, 1992, 1992a; also Norris 2000 and Norris 1993.) Thus Derrida expressly repudiates the kinds of wholesale anti-enlightenment thinking associated chiefly with postmodernist thinkers like Lyotard, and also - on related grounds - the sorts of dismissive or downright contemptuous attitude toward any talk of disinterest, aesthetic value, the sensus communis of shared critical judgement, and so forth, adopted by the current debunking school of thought (Lyotard 1984). To be sure, he devotes much of his argument in 'Parergon' and other middle-period writings to a detailed analysis of the way that those cardinal Kantian distinctions - all of which turn on some variant of the pure/impure dichotomy - can be shown to break down, under deconstructive pressure, into further such valueladen binaries (like 'free' versus 'adherent' beauty) that are no more capable of holding up when subject to critical reading. All the same, as I have said, Derrida is very firm in maintaining the 'absolute and principled' necessity that those aims, values and priorities should be kept constantly in view as the only means by which thinking can orient itself toward a better understanding of the various factors and forces that work against their attainment as a matter of ethical or socio-political justice.

This is why philosophy takes its place on the 'left bench' of the Kantian parliament of the faculties, that is to say, as a discipline utterly remote from the centres of executive or legislative power. Yet it is a faculty which, for that very reason, should be granted the freedom to question and criticise any uses or abuses of such power, or indeed any item of received belief - political, moral, or theological - that might be enjoined upon those right-bench occupants whose executive status allows them no equivalent freedom. (See Kant 1979 and Kant 1976.) This is also why the discourse of aesthetic judgement, concerned as it is (on the Kantian account) with matters at the furthest possible remove from the interests of government and state, should none the less be seen - and again, for just that reason - as embodying certain, albeit as yet unrealised and perhaps unrealisable values which offer a constant implicit critique of the executive branch. So it can hardly be denied that Derrida's reading goes various elaborate ways around in order to question or to deconstruct the concepts, categories, and presuppositions of Kantian formalist aesthetics. However - and it is here that the New Musicologists have most to learn - it does so always in such a way as to conserve their critical valence and thereby maintain the critical tension between this way of thinking (or the kinds of experience envisaged by its advocates) and the conditions under which it must presently remain a discourse marked by various kinds of contaminating ideological influence. Given time, one could trace this nexus of themes right back to some of Derrida earliest essays where they are engaged by way of the conflict of interpretations between, on the one hand, a structuralist approach that treats the literary text as an autonomous, self-referential, ahistorical entity and, on the other, a phenomenological approach that treats it as expressing - inevitably so - a wide range of sociocultural as well as individual or subjective meanings. (See especially Derrida 1978.) Here again 
he adopts not a blandly accommodating line that would simply defuse the issue but, in the strictest sense, a deconstructive mode of engagement that locates the precise points of tension, aporias, or methodological blind-spots on both sides so as to achieve a more adequate grasp of the interests and commitments at stake.

My point in all this is that the New Musicologists - or some of them - have been too quick to claim Derridean warrant for certain of their claims with regard to the bankrupt, ideologically complicitous character of music analysis in general and (more specifically) formalist notions of structural listening or long-range thematic and tonal integration. What is being played out in these somewhat predictable debates - like that between Dunsby and Street - is yet another version of the well-worn 'analytic' versus 'continental' spat in recent (mainly Anglophone) philosophy. Thus analytical types charge the continentals with indulging deplorably lax standards of conceptual clarity and grasp while the latter see nothing in that rival discourse but a narrowminded professionalism which treats all philosophy as aspiring to the strictly self-evident (hence tautological or vacuous) status of the analytic proposition. (For further discussion, see Norris 2000a.) If there is one area of study where such pseudo-dilemmas should have no place it is that of music criticism, taken (one would hope uncontroversially) to embrace whatever kinds of approach can be shown to enhance our understanding of and pleasure in the experience of music. No doubt there are some theorists who will indeed controvert the naïve or hopefully ecumenical assumption underlying that last sentence. That is, they will take issue with the joint claim that better, more refined or structurally informed understanding is itself a great source of musical pleasure, and again, that such pleasure is by no means just an unwitting product of 'aesthetic ideology' or a mere distraction from the sorts of hard-headed Ideologiekritik that would expose its less-than-edifying cultural and socio-political origins. Amongst them, as I have said, are certain deconstructive musicologists who cast a cold eye on the very idea - the 'eudaimonic' delusion, in de Man's parlance - that pleasure might have any significant role to play in an undeceived, rigorous, critically alert response to those works (or to the discourse about them) that solicit our enjoyment on terms unacceptable by any such exacting standard (Man 1986).

All the more ironic, therefore, that these theorists should also have taken to denouncing formal-structural 'analysis' as an adjunct to the strain of aesthetic ideology which supposedly promotes this complicity with suspect modes of musical experience. After all, until quite recently - in fact, around the time of Kerman's landmark intervention - the main dispute within music criticism was that between 'appreciative' and 'analytic' schools of thought, a dispute going back (as I mentioned at the start of this essay) to the early days of textual close-reading as a literary-critical method. So it is strange, and a symptom of the currently widespread 'hermeneutics of suspicion', that we should now have a sizeable number of music theorists - something like a new orthodoxy - for whom both approaches must be treated with the utmost caution (or even rejected tout court) since they each bear witness to the powerful hold of an aesthetic creed that exerts, in de Man's admonitory phrase, a decisive claim on the 'shape and limits of our freedom'. (See especially Man 1984a.) It seems to me, for reasons argued above, that one unfortunate result of such over-zealous transpositions from one domain (literary theory) to another (music criticism) is to dictate the shape and limits of our musical experience in a way that excludes - or at any rate sternly disapproves - just about everything which gives that experience its ultimate meaning and value.

This is not to deny - far from it - that theory, including those particular strains that I have criticised here, has a proper and legitimate place in musicological discourse. So it does, to be sure, in all areas or disciplines of thought where a refusal to theorise most often betokens either 
sheer intellectual laziness or (as the deconstructors would claim) an unthinking adherence to received ideologies whose own theoretical content is passed off as straightforward, natural, or common-sense wisdom. Besides, it follows from my brief excursion into the field of cognitive psychology that our experience of music can often be affected - significantly changed or enhanced - not only by the reading of perceptive music analyses but also by acquaintance with certain theoretical ideas, among them (quite possibly) those advanced by deconstructive musicologists. (On this topic more generally, see Aiello / Sloboda 1993; Deutsch 1999; Dowling / Harwood 1986; Sloboda 1985.) Thus, for instance, our understanding/appreciation of Beethoven's late quartets (or the Brahms piano pieces discussed by Alan Street) might well stand to gain through our taking account of those features that hold out against any overly 'organicist' interpretation. Indeed, this idea that musical value may have to do precisely with the conflict or tension between background norms of structural unity and other, more disruptive foreground elements is one that finds favour even with critics, like Leonard Meyer, who are often pilloried by the New Musicologists as slavish adherents to the old formalist paradigm. (See for instance Meyer 1965.) Yet it is hard to see how such an argument could work, or such values apply, were it not for those same normative expectations - of structural development, thematic contrast, tonal progression, and so forth - which constitute a point of reference and departure for whatever strikes the well-attuned listener as marking a break with established modes of compositional practice.

Still less could it work on the curious premise - one shared, be it noted, not only by de Man but also by a high formalist like Kant - that any taint of sensuous experience in our thinking about issues of aesthetic worth or (in the present context) of musical structure and meaning must betoken, as Kant puritanically puts it, a 'pathological' admixture of motives or desires at odds with the purely disinterested character of true aesthetic evaluation (Kant 1978). While the New Musicologists are pretty much united in rejecting Kant's claims for aesthetic disinterest, formal autonomy, 'pure' as opposed to 'impure' modes of judgement, and so forth, they are oddly in accord when it comes to his deep mistrust of that whole dimension of aesthetic experience where the pleasures of sensuous apprehension are closely bound up with those of cognitive understanding and structural grasp. What this gives us, in effect, is the worst of both worlds: an approach whose foregone theoretical commitments enjoin us to renounce (or at any rate to treat with the greatest suspicion) not only the sensuous experience of music but also the heightened pleasure and appreciation that comes of an informed musical understanding. I have suggested that such thinking takes rise from a number of erroneous premises, chief among them the idea that structural analysis must always entail the subscription to some kind of doctrinaire organicist creed, thus revealing the grip of an aesthetic ideology that naïvely conflates the realm of linguistic signification with the realm of natural processes or forms. However this idea is itself the result of a drastic and unwarranted conflation. That is to say, it extrapolates directly from the domain of literary theory - which of course has to do with linguistic texts and where the argument thus has a certain force against the more naïve and perhaps ideologically-loaded sorts of naturalistic fallacy - to the domain of music criticism where altogether different considerations apply.

Along with this goes the claim - with its primary source, again, in de Man's writings - that any appeal to the sensory-perceptual experience of music is likewise suspect by reason of that same delusory grounding in those natural phenomena (e.g., the tonal system or overtoneseries) that constitute the essence of musical meaning and value. To be sure, such notions if pushed to an extreme have shown themselves amenable to ideological uses, as for instance in Schenker's chauvinist application of them and in kindred claims for the hegemonic status of 
the 'mainstream', 'classical', i.e., Austro-German musical tradition. They are also quite explicit - ironically enough, given his life-history and fervent opposition to any such creed when deployed to overtly nationalist ends - in Schoenberg's idea of the dodecaphonic system as ensuring the continued pre-eminence of that same tradition through its progressive exploration of harmonic resources that didn't so much break altogether with tonality as move further out along the overtone series or circle of fifths (Schoenberg 1984 and Schoenberg 1995). However it is absurd to suppose that there always must be some deep-laid ideological bias at work whenever critics, analysts, or musically-informed listeners betray some adherence to the notion of music as gaining much of its expressive power through the affinity that exists between certain tonal or harmonic structures and certain modes of listener-response. Still less can it be warranted to take this as grounds for rejecting the idea that analysis might play a useful, pleasureenhancing, even (at times) transformative role in making the process more readily available to conscious, reflective understanding.

Empson got it right, I suggest, when he remarked in Seven Types of Ambiguity that poetic 'appreciation' has nothing to fear from exposure to verbal analysis since good poetry can only benefit from intelligent and perceptive close reading while the pleasures it affords are sufficiently robust to withstand other, less sensitive or tactful approaches (Empson 1930). The same is true of musical analysis and moreover - be it said - of music theory just so long as it doesn't invent a whole range of counter-intuitive and misconceived grounds for rejecting what analysis can fairly claim to offer, not only as a matter of formal demonstration but also in terms of heightened appreciative yield. After all, as Empson puts it, 'normal sensibility is a tissue of what has been conscious theory made habitual and returned to the pre-conscious, and, therefore, conscious theory may make an addition to sensibility' (Empson 1930: 254). And again: 'the act of knowing is itself an act of sympathising; unless you are enjoying the poetry you cannot create it, as poetry, in your mind' (Empson 1930: 253). It seems to me that these claims are strongly borne out by a good deal of recent work in cognitive psychology as well as by the way that a critic like Rosen - one with a wide range of philosophic as well as literary, cultural-historical, and of course music-analytical interests - can provide such a depth of musical insight as to render any charge of 'aesthetic ideology' (in his case at least) just a tedious irrelevance. Where theory works to best, most telling effect is not so much by advancing wholesale diagnoses in the deconstructionist mode but rather by promoting a more reflective awareness of how music relates to the various discourses - those of analysis and historiography among them - which undoubtedly inform our perceptual responses yet not to the point of though-and-through ideological conditioning envisaged by some current thinkers.

\section{Literature}

Adorno, Theodor W. (1973). Philosophy of Modern Music. London: Sheed \& Ward

Adorno, Theodor W. (1974). Negative Dialectics. London: Routledge \& Kegan Paul.

Adorno, Theodor W. (1982). 'On the Problem of Music Analysis'. In: Music Analysis, Vol. 1, No. 2, 170-87.

Adorno, Theodor W. (1991). The Culture Industry: selected essays on mass culture. London: Routledge.

Adorno, Theodor W. (1991a). Alban Berg: master of the smallest link. Cambridge: Cambridge University Press.

Adorno, Theodor W. (1991b). In Search of Wagner. London: Verso. 
Adorno, Theodor W. (1997). Aesthetic Theory. London: Athlone.

Adorno, Theodor W. (1998). Quasi Una Fantasia: essays on modern music. London: Verso.

Adorno, Theodor W. (1998a). Beethoven: the philosophy of music. Oxford: Polity Press.

Aiello, Rita / Słoboda, John (eds.) (1993). Musical Perceptions. New York: Oxford University Press.

Baker, James M. / Beach, David W. / Bernard Jonathan W. (eds.) (1977). Music Theory in Concept and Practice. Rochester, NY: University of Rochester Press.

Barthes, Roland (1975). S/Z. London: Cape.

Barthes, Roland (1976). The Pleasure of the Text. London: Jonathan Cape.

Barthes, Roland (1977). Image-Music-Text. London: Fontana.

Barthes, Roland (1977a). Roland Barthes by Roland Barthes. London: Macmillan.

Barthes, Roland (1984). Mythologies. New York: Hill \& Wang.

Beach, David (ed.) (1983). Aspects of Schenkerian Theory. New Haven: Yale University Press.

Bent, Ian / Drabkin, William (1987). Analysis. Basingstoke: Macmillan Press.

Bergeron, Katherine / Bohlman, Philip V. (eds.) (1992). Disciplining Music: musicology and its canons. Chicago: University of Chicago Press.

Bourdieu, Pierre (1984). Distinction: a social critique of the judgement of taste. Cambridge, MA: Harvard University Press.

Blasius, Leslie D. (1996). Schenker's Argument and the Claims of Music Theory. Cambridge: Cambridge University Press.

Briel, Holger / Kramer, Andreas (eds.) (2001). In Practice: Adorno, critical theory, and cultural studies. New York: Peter Lang.

Brooks, Cleanth (1947). The Well Wrought Urn: studies in the structure of poetry. New York: Harcourt Brace.

Burnham, Scott (1996). 'A.B. Marx and the Gendering of Sonata Form'. In: Ian Bent (ed.). Music Theory in the Age of Romanticism. Cambridge: Cambridge University Press, 163-186.

Cook, Deborah (1996). The Culture Industry Revisited: Theodor W. Adorno on mass culture. Lanham, MD: Rowman \& Littlefield.

Cook, Nicholas (1989). 'Music Theory and "Good Comparison«: a Viennese perspective'. In: Journal of Music Theory, Vol. 33, 117-142.

Cook, Nicholas (1993). A Guide to Musical Analysis. Oxford: Oxford University Press.

Cook, Nicholas (1996). Analysis through Composition. Oxford: Oxford University Press.

Cook, Nicholas / Everist, Mark (eds.) (1999). Re-Thinking Music. Oxford: Oxford University Press.

DeBellis, Mark A. (1995). Music and Conceptualization. Cambridge: Cambridge University Press.

Dempster, Douglas / Brown, Matthew (1990). 'Evaluating Musical Analyses and Theories: five perspectives'. In: Journal of Music Theory, Vol. 34, 247-280.

Derrida, Jacques (1976). Of Grammatology. Baltimore, MD: Johns Hopkins University Press.

Derrida, Jacques (1978). 'Structure, Sign and Play in the Discourse of the Human Sciences'. In: Jacques Derrida. Writing and Difference. London: Routledge \& Kegan Paul, 278-93.

Derrida, Jacques (1978a). 'Force and Signification'. In: Writing and Difference. London: Routledge \& Kegan Paul, 3-30.

Derrida, Jacques (1980). Dissemination. London: Athlone Press.

Derrida, Jacques (1982). Margins of Philosophy. Chicago: University of Chicago Press.

Derrida, Jacques (1983). 'The Principle of Reason: the university in the eyes of its pupils'. In: Diacritics, Vol. 19, 3-20. 
Derrida, Jacques (1987). 'Parergon'. In: Jacques Derrida. The Truth in Painting. Chicago: University of Chicago Press, 15-147.

Derrida, Jacques (1989). Limited Inc. Evanston, IL: Northwestern University Press.

Derrida, Jacques (1992). 'Mochlos, or the Conflict of the Faculties'. In: Derrida, Jacques. Logomachia. Lincoln and Nebraska: University of Nebraska Press, 3-34.

Derrida, Jacques (1992a). 'Of an Apocalyptic Tone Newly Adopted in Philosophy'. In Coward, Harold / Foshay, Toby (eds.). Derrida and Negative Theology. Albany, NY: State University of New York Press, 24-71.

Deutsch, Diane (ed.) (1999). The Psychology of Music. San Diego: Academic Press.

Dowling, W. Jay / Harwood, Diane L. (1986). Music Cognition. San Diego: Academic Press.

Dunsby, Jonathan (1981). Structural Ambiguity in Brabms: analytical approaches to four works. Ann Arbor: UMI Research Press.

Dunsby, Jonathan (1983). 'The Multi-Piece in Brahms: Fantasien, Op. 116'. In: Robert Pascall (ed.). Brahms: biographical, documentary and analytical studies. Cambridge: Cambridge University Press, 167-189.

Dunsby, Jonathan / Whittall, Arnold (1988). Music Analysis in Theory and Practice. New Haven: Yale University Press).

Empson, William (1930). Seven Types of Ambiguity. London: Chatto \& Windus.

Empson, William (1987). 'O Miselle Passer'. In: John Haffenden (ed.). Argufying: essays on literature and culture. London: Chatto \& Windus, 193-202.

Fodor, Jerry A. (1976). The Language of Thought. Hassocks: Harvester Press.

Fodor, Jerry A. (1983). The Modularity of Mind: an essay on faculty psychology. Cambridge, MA: MIT Press.

Fodor, Jerry A. (1989). A Theory of Content and other essays. Cambridge, MA: MIT Press.

Fodor, Jerry A. (2000). The Mind Doesn't Work That Way: the scope and limits of computational psychology. Cambridge, MA: MIT Press.

Forte, Allen / Gilbert, Steven E. (1982). Introduction to Schenkerian Analysis. New York: Norton.

Gasché, Rodolphe (1998). The Wild Card of Reading: on Paul de Man. Cambridge, MA: Harvard University Press.

Gibson, Nigel / Rubin, Andrew (eds.) (2002). Adorno: a critical reader. Oxford: Blackwell.

Goehr, Lydia (1992). The Imaginary Museum of Musical Works: an essay in the philosophy of music. Oxford: Clarendon Press.

Hanslick, Eduard (1986). On the Musically Beautiful: a contribution towards the revision of the aesthetics of music. Indianapolis, IN: Hackett Publishing.

Jankélevitch, Vladimir (1951). Gabriel Fauré: ses mélodies, son esthétique. Paris: Plon.

Jankélevitch, Vladimir (1959). Ravel. New York: Grove Press.

Kant, Imannuel (1976). Political Writings. Cambridge: Cambridge University Press.

Kant, Imannuel (1978). Critique of Judgement. Oxford: Clarendon Press.

Kant, Imannuel (1979). The Conflict of the Faculties. New York: Abaris Books.

Kerman, Joseph (1962). The Elizabethan Madrigal: a comparative study. New York: American Musicological Society.

Kerman, Joseph (1967). The Beethoven Quartets. Oxford: Oxford University Press.

Kerman, Joseph (1980). 'How we got into analysis, and how to get out'. In: Critical Inquiry, Vol. 7, 311-331.

Kerman, Joseph (1981). The Masses and Motets of William Byrd. London: Faber.

Kerman, Joseph (1983). 'A Few Canonic Variations'. In: Critical Inquiry, Vol. 10, 107-125. 
Kerman, Joseph (1985). Musicology. London: Fontana, 1985.

Kivy, Peter (2001). New Essays on Musical Understanding. Oxford: Oxford University Press.

Korsyn, Kevin (1993). 'Brahms Research and Aesthetic Ideology'. In: Music Analysis, Vol. 12, 89-103.

Kramer, Lawrence (1995). Classical Music and Postmodern Knowledge. Berkeley \& Los Angeles: University of California Press.

Lacoue-Labarthe, Philippe / Nancy, Jean-Luc (1988). The Literary Absolute: the theory of literature in German Romanticism. Albany, NY: State University of New York Press.

Lerdahl, Fred / Jackendoff, Ray (1983). A Generative Theory of Tonal Music. Cambridge, MA: MIT Press).

Levinson, Jerrold (1997). Music in the Moment. Ithaca, NY: Cornell University Press.

Lyotard, Jean-François (1984). The Postmodern Condition: a report on knowledge. Manchester: Manchester University Press.

Lochhead, Judy / Auner, Joseph (eds.) (2002). Postmodern Music/Postmodern Thought. New York \& London: Garland.

Lodge, David (1977). The Modes of Modern Writing: metaphor, metonymy, and the typology of modern literature. London: Edward Arnold.

Man, Paul de (1979). Allegories of Reading: figural language in Rousseau, Nietzsche, Rilke, and Proust. New Haven: Yale University Press.

Man, Paul de (1983). Blindness and Insight: essays in the rbetoric of contemporary criticism. London: Methuen.

Man, Paul de (1984). The Rhetoric of Romanticism. New York: Columbia University Press.

Man, Paul de (1984a). 'Aesthetic Formalization in Kleist'. In: Man 1984, 263-290.

Man, Paul de (1986). The Resistance to Theory. Manchester: Manchester University Press.

Man, Paul de (1996). Aesthetic Ideology, Minneapolis: University of Minnesota Press.

McClary, Susan (1981). Feminine Endings: music, gender, and sexuality. Minneapolis: University of Minnesota Press.

McClary, Susan (2000). Conventional Wisdom: the content of musical form. Berkeley \& Los Angeles: University of California Press.

Meyer, Leonard B. (1965). Music, the Arts, and Ideas. Chicago: University of Chicago Press.

Narmour, Eugene (1977). Beyond Schenkerism: the need for alternatives in music analysis. Chicago: University of Chicago Press.

Norris, Christopher (1988). Paul de Man: deconstruction and the critique of aesthetic ideology. New York: Routledge.

Norris, Christopher (1993). 'Kant Disfigured: ethics, deconstruction, and the textual sublime'. In: The Truth About Postmodernism. Oxford: Blackwell, 182-256.

Norris, Christopher (2000). Deconstruction and the "Unfinished Project of Modernity". London: Athlone Press.

Norris, Christopher (2000a). Minding the Gap: epistemology and philosophy of science in the two traditions. Amherst, MA: University of Massachusetts Press.

Norris, Christopher (2003). 'Derrida on Rousseau: deconstruction as philosophy of logic'. In Norris and David Roden (eds.) (2003). Jacques Derrida. London: Sage, Vol. 2/4, 70-124.

Paddison, Max (1996). Adorno, Modernism and Mass Culture: essays on critical theory and music. London: Kahn \& Averill.

Pople, Anthony (1994). Theory, Analysis, and Meaning in Music. Cambridge: Cambridge University Press.

Reichenbach, Hans (1938). Experience and Prediction. Chicago: University of Chicago Press. 
Rosen, Charles (1975). Arnold Schoenberg. New York: Viking Press.

Rosen, Charles (1976). The Classical Style. London: Faber.

Rosen, Charles (1994). 'Music à la Mode'. In: The New York Review of Books, Vol. 41, No. 12 (June $23^{\text {rd }}$ ).

Rosen, Charles (1996). The Romantic Generation. London: Harper-Collins.

Rosen, Charles (2000). Critical Entertainments: music old and new. Cambridge, MA: Harvard University Press.

Saussure, Ferdinand de (1974). Course in General Linguistics. London: Fontana.

Schenker, Heinrich (1973). Harmony. Cambridge, MA: MIT Press.

Schenker, Heinrich (1979). Free Composition. New York: Longman.

Schoenberg, Arnold (1984). Style and Idea: selected writings of Arnold Schoenberg. London: Faber.

Schoenberg, Arnold (1995). The Musical Idea and the logic, technique, and art of its presentation. New York: Columbia University Press.

Siegel, Hedi (ed.) (1990). Schenker Studies. Cambridge: Cambridge University Press.

Sloboda, John (1985). The Musical Mind: the cognitive psychology of music. Oxford: Oxford University Press.

Solie, Ruth A. (1980). 'The Living Work: organicism and musical analysis'. In: NineteenthCentury Musicology, Vol. 4, 147-56.

Solie, Ruth A. (ed.) (1993). Musicology and Difference. Berkeley \& Los Angeles: University of California Press.

Sparrow, John (1930). 'Practical Criticism: A Reply to Mr. Empson'. In: Oxford Outlook, Vol. 10 (Nov.), 5982607.

Street, Alan (1989). 'Superior Myths, Dogmatic Allegories: the resistance to musical unity'. In: Music Analysis, Vol. 8, 77-123.

Subotnik, Rose Rosengard (1991). Developing Variations: style and ideology in Western music. Minneapolis: University of Minnesota Press.

Subotnik, Rose Rosengard (1996). Deconstructive Variations: music and reason in Western society. Minneapolis: University of Minnesota Press.

Treitler, Leo (1989). 'Music Analysis in a Historical Context'. In: Leo Treitler. Music and the Historical Imagination. Cambridge, MA: Harvard University Press, 67-78.

Tuve, Rosamond (1952). A Reading of George Herbert. London: Faber.

Wimsatt, William K. (1954). The Verbal Icon: studies in the meaning of poetry. Lexington, KY: University of Kentucky Press.

Yeston, Maury (ed.) (1977). Readings in Schenker Analysis and other approaches. New Haven: Yale University Press. 